\title{
Pond Substrate Type Affects Yellow Perch Fingerling Size at Harvest
}

\author{
Matthew J. Ward \\ South Dakota Department of Game, Fish and Parks, Blue Dog State Fish Hatchery, Waubay, USA \\ Email: matthew.ward@state.sd.us
}

How to cite this paper: Ward, M.J. (2021) Pond Substrate Type Affects Yellow Perch Fingerling Size at Harvest. Open Journal of Animal Sciences, 11, 31-36.

https://doi.org/10.4236/ojas.2021.111003

Received: December 22, 2020

Accepted: January 24, 2021

Published: January 27, 2021

Copyright ( 2021 by author(s) and Scientific Research Publishing Inc. This work is licensed under the Creative Commons Attribution International License (CC BY 4.0).

http://creativecommons.org/licenses/by/4.0/

\begin{abstract}
Fish size and harvest density generally exhibit a negative relationship in pond culture, but the influence that pond substrate type can have on this relationship is not well understood. To evaluate the influence of pond substrate type on yellow perch (Perca flavescens), harvest density (number/hectare) was linearly regressed against individual fingerling size (grams) for lined $(\mathrm{n}=48)$ and earthen $(\mathrm{n}=40)$ substrate ponds that were treated similarly in terms of organic fertilizer use and the number of days in the pond over 12 culture seasons at Blue Dog Lake State Hatchery, South Dakota, USA. Harvest density explained 45 and $39 \%$ of the variation in yellow perch size in lined and earthen-substrate ponds (all $P<0.01$ ). Comparison of regression lines indicated that fingerling size decreased as harvest density increased at a similar rate in both pond types (slope comparison, $P=0.62$ ); however, fingerling size was significantly larger in lined ponds regardless of density that varied from near 0 to 700,000 per hectare (y-intercept comparison, $P<0.01$ ). At the same harvest density, lined ponds will tend to produce larger yellow perch fingerlings compared to earthen ponds when similar organic fertilizers are used.
\end{abstract}

\section{Keywords}

Yellow Perch, Pond Culture, Pond-Substrate Type

\section{Introduction}

Yellow Perch (Perca flavescens) are reared in ponds because large numbers of fingerlings can be raised using natural, invertebrate prey with relatively little cost [1] [2]. As fish density increases, fingerling size generally decreases owing to a density-dependent response with slower growth [1] [3] [4]. This can lead to a reduced availability of fish if larger fingerlings are required or affect the length of the pond culture interval [5]. Some culturists prefer smaller yellow perch (17 to 
$25 \mathrm{~mm} \mathrm{TL}$ ), which permits high harvest densities (e.g., 500,000 per hectare [2]), while others sacrifice numbers to produce larger fingerlings $(75 \mathrm{~mm} \mathrm{TL}$ ) for stocking into waters with predators [6]. Ultimately, the tradeoff between individual fish size and harvest number is a regular consideration for pond culturists.

Both lined and earthen-substrate ponds are used to rear yellow perch [5]. However, the only side-by-side comparisons of fingerling harvest metrics between these substrate types occurred with walleye (Sander vitreus) where lined ponds produced either larger fingerlings at a similar harvest density [7] or more fingerlings without sacrificing fingerling size [8]. The objective of this research was to evaluate if yellow perch fingerling size varied across harvest density between lined and earthen-substrate ponds.

\section{Methods}

\subsection{Pond Culture}

This study was conducted at Blue Dog State Fish Hatchery near Waubay, South Dakota, USA ( $\left.45^{\circ} 21^{\prime} 30.89^{\prime \prime} \mathrm{N}, 97^{\circ} 19^{\prime} 03.63^{\prime \prime} \mathrm{W}\right)$ between 2008 and 2019 when yellow perch were reared in both ethylene propylene diene monomer lined $(\mathrm{n}=48)$ and earthen-substrate $(n=40)$ ponds that had surface areas varying between 0.12 and 0.72 hectares (Figure 1). All ponds were filled with unfiltered Blue Dog Lake water and were stocked with yellow perch as eyed eggs or force hatched fry [1]. Egg source varied among lakes located throughout eastern South Dakota over the course of this study, but was similar within a year for both pond types. Lined ponds tended to be stocked with higher numbers of yellow perch as initial data suggested a higher production potential [7] (Table 1). The earliest pond rearing interval began on April 26 and the latest interval ended on July 2. Overall
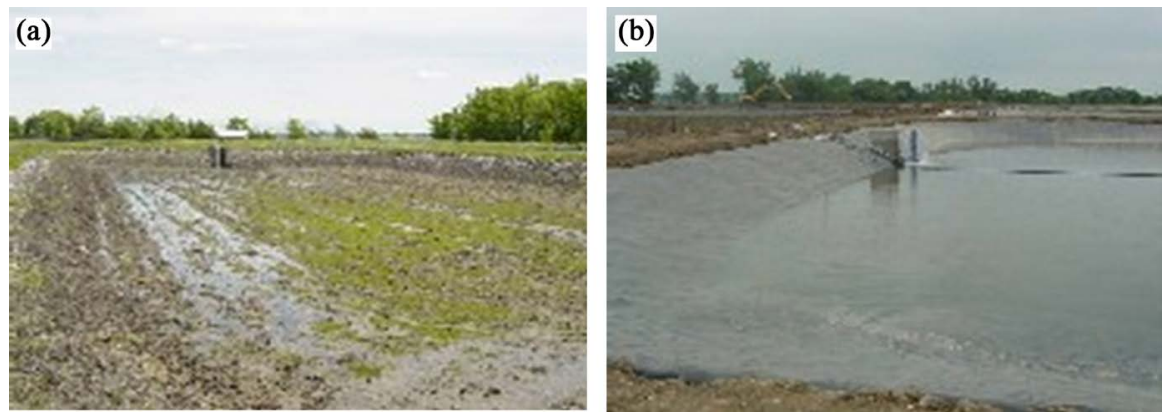

Figure 1. Earthen-(a) and ethylene propylene diene monomer-lined; (b) ponds at Blue Dog State Fish Hatchery, Waubay, South Dakota, USA.

Table 1. Means ( \pm SE) for yellow perch stocking density (number/ha), rearing period (days) and organic fertilizer (kg/ha) applied during 2008 through 2019 in lined and earthen-substrate ponds at Blue Dog State Fish Hatchery.

\begin{tabular}{cccccc}
\hline Substrate Type & Stocking Density & Rearing Period & Alfalfa & Soybean meal & Yeast \\
\hline Lined & $485,989(23,502)$ & $45(1)$ & $572(24)$ & $37(10)$ & $31(4)$ \\
Earthen & $340,432(19,607)$ & $45(1)$ & $610(15)$ & $51(16)$ & $33(3)$ \\
\hline
\end{tabular}


climate conditions during these comparisons were typical of late April through early July for the northern Great Plains of North America with a general warming trend as the pond interval progressed each year. The mean duration of the rearing interval as well as fertilizer use is reported in Table 1. Fertilizer use was based upon previous experience of staff at Blue Dog State Fish Hatchery.

\subsection{Harvest Metrics}

Individual ponds were harvested by draining water while maintaining yellow perch fingerlings in a screened catch basin. From the catch basin, a random sample of at least 150 fingerlings was cumulatively weighed and used to determine the number of fish per kilogram. Harvest weight was determined by weighing nets filled with yellow perch fingerlings to the nearest 0.22 kilograms then summing all weights after fish had been removed. The number of fish harvested was calculated with Equation (1), which was

kilograms harvested $\times$ fish per $\mathrm{kg}=$ number of fish harvested.

Number of fish and weight harvested were then divided by the surface area of the pond to present density (no./ha) and yield ( $\mathrm{kg} / \mathrm{ha}$ ) metrics. The reciprocal of fish per $\mathrm{kg}$ was used to represent individual fish size following conversion to grams.

The majority of the ponds were harvested individually; however, due to the need to expedite pond harvest and reduce labor costs in certain years, $15 \%$ of the ponds were harvested so that fish from two ponds of the same substrate type and surface area were in the catch basin at the same time. In these instances, the total number of fish and weight removed from the catch basin were split evenly between the ponds and the fish size was same for both ponds.

\subsection{Statistics}

Linear regression was used to assess the relationship and determine how much of the variation in fish size was being explained by harvest density in both pond substrate types. ANCOVA assessed if these significant regression lines (i.e., slopes and y-intercepts) differed. Significance was set at 0.05 for all relationships and all analyses were performed using Systat 12 (Systat Software, Inc., San Jose, California, USA).

\section{Results}

Yellow perch fingerling size (grams) varied between 0.08 to 1.26 for earthen and 0.12 to 1.38 for lined ponds, while harvest density (number/ha) varied from 3000 to 588,055 in earthen and 6333 to 692,333 in lined ponds. Yellow perch fingerling size and harvest density exhibited negative relationships in both pond types. Density explained $45 \%$ of the variation in fingerling size in lined and $39 \%$ in earthen ponds (Figure 2). Comparison of the regression lines revealed no difference in slope (F-ratio $=0.25, P=0.62$ ) indicating that as density increased fingerling size decreased at a similar rate between pond types. However, lined 


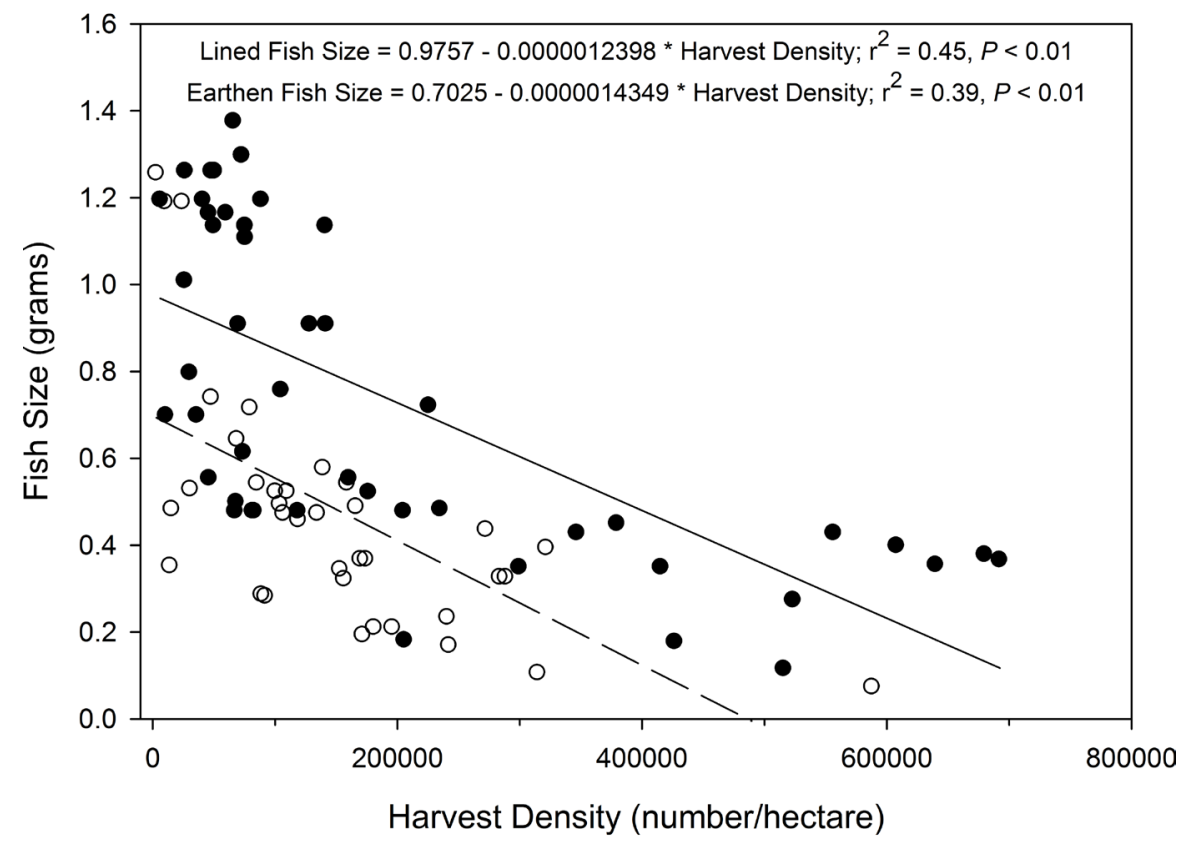

Figure 2. Yellow perch fingerling size (grams) as a function of harvest density (number/hectare) in lined and earthen-substrate ponds during 2008 through 2019. The lined pond relationship is represented by filled circles and a solid line while the earthen pond relationship is in unfilled circles and a dashed line.

ponds exhibited a significantly higher $\mathrm{y}$-intercept value (F-ratio $=33.00, P<$ 0.01 ) demonstrating a tendency to produce larger individual yellow perch across all densities examined (Figure 2).

\section{Discussion}

Lined ponds increased yellow perch fingerling size across a range of harvest densities varying from near 0 to approximately 700,000 per hectare. Likewise, walleye fingerling size was increased in lined ponds compared to earthen-substrate ponds when harvest density was similar [7]. Because the culture duration averaged 45 days for both pond types, the increased size of fingerling yellow perch implies an increased rate of growth in the lined ponds. This was observed with walleye, as early as 15 to 20 days into the culture interval [7] [8].

Yellow perch fingerling size and harvest density were variable in both pond types, which was not uncommon [1] [5]. As yellow perch density increased, their individual size decreased in both pond types. Smaller fishes are typically produced at higher densities because forage resources become limiting [5]. This data suggested that yellow perch forage resources were more likely to become limiting in earthen ponds as their size tended to be smaller across all densities. Other negative aspects of limited forage include size heterogeneity that increases the likelihood of cannibalism [5].

At a fingerling size of 0.38 grams, a lined pond would have the tendency to more than double the number of fingerlings compared to an earthen pond of the same surface area and supports the use of higher stocking densities. This 
long-term dataset provides additional information that a pond with an exposed-liner substrate can enhance percid fingerling numbers of a given size when similar organic fertilizer is used. The previous study with walleye and this study were conducted at the same hatchery, so whether a lined pond would have a similar effect at other locations with differing rearing conditions is unknown.

Lining additional ponds is expensive, so developing strategies to increase yellow perch harvest density without sacrificing fingerling size in earthen-substrate ponds could be cost effective. Recent information suggests that lined ponds use organic fertilizer more efficiently to increase the pelagic signature of the food web compared to earthen ponds [8]. Future efforts to enhance the pelagic signature of the food web through fertilizer manipulation may allow yellow perch harvest density to be increased without sacrificing fingerling size in earthensubstrate ponds at this facility.

\section{Acknowledgements}

Thanks to Blue Dog Hatchery staff including J. Broughton, R. Smidt, R. Rasmus, N. Pool, C. Haabala, and E. Holm for collecting data and fish culture duties that led to the publication of these data. Partial funding was provided by the Federal Aid to Sportfish Restoration Project F-41-D-14.

\section{Conflicts of Interest}

The author declares no conflicts of interest regarding the publication of this paper.

\section{References}

[1] Hart, S.D., Garling, D.L. and Malison, J.A. (2006) Yellow Perch Culture Manual. NCRAC Culture Series 103. North Central Regional Aquaculture Center Publications Office, Iowa State University, Ames.

[2] Held, J.A., Malison, J.A. and Kuczynski, T.E. (1998) Techniques for Commercial Production of Feed-Trained Yellow Perch (Perca flavescens) Fingerlings. World Aquaculture Society Book of Abstracts 29th Annual Meeting of the World Aquaculture Society, Las Vegas, 16-19 February 1998, 239.

[3] Piper, R.G., McElwain, I.B., Orme, L.E., McCraren, J.P., Fowler, L.G. and Leonard, J.R. (1982) Fish Hatchery Management. U.S. Fish and Wildlife Service, Washington DC.

[4] Culver, D.A., Madon, S.P. and Qin, J. (1993) Percid Pond Production Techniques: Timing, Enrichment, and Stocking Density Manipulation. Journal of Applied Aquaculture, 2, 9-31. https://doi.org/10.1300/J028v02n03_02

[5] Kestemont, P., Melard, C., Held, J. A. and Dabrowski, K. (2015) Culture Methods of Eurasian Perch and Yellow Perch Early Life Stages. In: Kestemont, P., Dabrowski, K. and Summerfelt, R.C., Eds., Biology and Culture of Percid Fishes, Springer, New York, 265-294. https://doi.org/10.1007/978-94-017-7227-3_9

[6] Lundgren, S.A., Schoenebeck, C.W., Koupal, K.D., Lorensen, J.A. and Huber, C.G. (2014) Quantification and Evaluation of Factors Influencing Largemouth Bass Predation of Stocked Advanced Fingerling Yellow Perch. North American Journal of Fisheries Management, 34, 595-601. https://doi.org/10.1080/02755947.2014.901260 
[7] Ward, M.J., Uphoff, C., Stane, J., Borah, B., Henry, A., Billings, J. and Johnson, B. (2011) Walleye Fingerling Culture in Earthen and Ethylene Propylene Diene Monomer-Lined Ponds. North American Journal of Aquaculture, 73, 1-7.

[8] Ward, M.J. and Blackwell, B.G. Factors Associated with Increased Walleye Fingerling Production in Lined Compared to Earthen-Substrate Ponds. Open Journal of Animal Sciences, in Press. 